\title{
US free-speech law offers protection - at a price
}

\section{Some fear that law to aid whistle-blowers will expose researchers to smear campaigns.}

\section{BY EUGENIE SAMUEL REICH}

$\mathrm{D}$ aniel Klessig has had two open-heart surgeries in the past eight years, and would gladly have two more rather than face another lawsuit like the one brought against him by Meena Chandok, his former postdoctoral researcher, in 2005 after Klessig alleged that she had falsified data.

"It is the worst thing that ever happened in my life," says Klessig, who studies plant immunology at the Boyce Thompson Institute for Plant Research (BTI) in Ithaca, New York.

An institutional inquiry ultimately exonerated Chandok of misconduct, but Klessig resoundingly defeated her lawsuit. The Court of Appeals for the Second Circuit in New York ruled on 13 January that he had a "legal or moral obligation" to describe his suspicions to journal editors, funding agencies and the BTI after other scientists were unable to replicate Chandok's work. But Klessig says that years of anxiety over how he would pay the hundreds of thousands of dollars that he might owe if he lost made the lawsuit a crippling burden.

Now, help may be at hand for whistleblowers like Klessig, in the form of legislation soon to be introduced in the US Congress. Known as the Citizen Participation Act, the law would, its advocates say, make it easier for whistle-blowers to call out suspect research without facing the threat of a costly defamation suit, because specific provisions would enable the whistle-blowers to claim back attorneys' fees from the plaintiff in the event that they won such a case. The effort parallels a libel-reform effort in the United Kingdom, where the Ministry of Justice is moving to ease the burden of notoriously plaintiff-friendly libel laws in England and Wales (see 'Revised English law may liberate scientific discussion').

Most scientists embrace the UK reforms, which would help them to fight defamation suits brought by companies. But the proposed
US law elicits mixed reactions. Whereas some experts say that it would free whistle-blowers to speak up, others worry that it could backfire by restricting informants' ability to sue when they themselves are attacked. According to David Lewis, director of the Research Misconduct Project at the National Whistleblowers Center in Washington DC, when government agencies or companies object to a scientist's work, "their most common tactic is to charge that scientist with false allegations of misconduct".

\section{A SLAPP IN THE FACE}

Lewis has personal experience with the matter. A former research microbiologist at the US Environmental Protection Agency, he was falsely accused of scientific misconduct in 2001 by Synagro Technologies, a biosolids company in Houston, Texas, after he investigated the possibility that sewage sludge spread on farm land had harmful effects on humans. The following year he responded with a defamation lawsuit that ended in a settlement with

\section{LEGAL REDRESS}

\section{Revised English law may liberate scientific discussion}

"In just 18 months, libel has gone from being an issue no one cared about to the verge of a new defamation bill," says Simon Singh, a British science writer. Last year, Singh (pictured) won a widely publicized suit brought by the British Chiropractic Association over comments that he had published in the newspaper The Guardian. His case, along with others in which scientists were sued by companies for publicly criticizing bad science, triggered a longawaited reform to English and Welsh libel law that is expected to be made public by the UK Ministry of Justice this week.

Singh expects the draft bill to include two measures that will redress the balance of a libel law that famously places undue burden on the defendant: he hopes it will prevent companies from having the same rights to reputation as individuals, and introduce a robust public-interest defence — something that the United States already has. "If I'm writing about a medical device or a drug

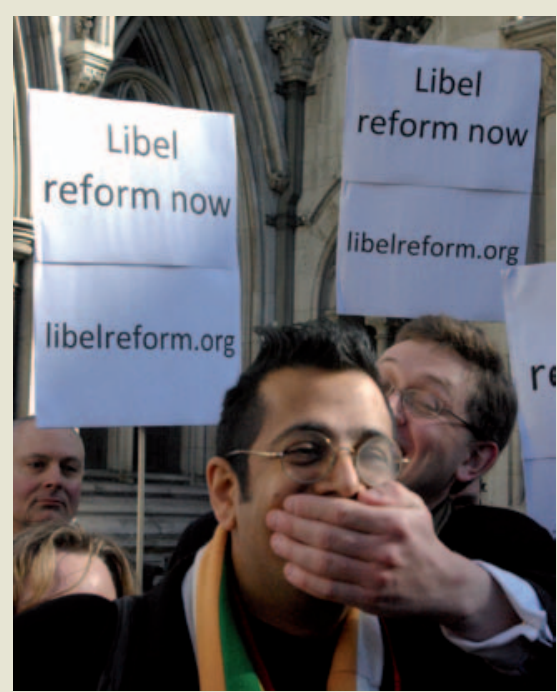

or an environmental issue, I should have additional protection," says Singh.

Sile Lane, campaigns manager for Sense about Science in London, which is pushing for libel reform, says that the use of libel law to shut down discussion is not the only problem with the system. It also discourages people with valid cases from suing.

"At present, an ordinary person who thinks they've been defamed in a national newspaper doesn't have access to the laws," she says. Cases take too long to adjudicate, resulting in large legal bills and substantial risk for both parties, which gives an advantage to the side with most money. Steps to simplify the law and bring down the costs of defamation cases for both sides are the subject of a separate government review.

In the United States, some argue that libel reform could leave scientists who have been the subject of smear campaigns with little legal recourse. But Singh says that in England, the law has until now been so restrictive that it is hard to imagine the balance moving too far in the other direction. E.S.R.

Nature supports the Libel Reform Campaign. 
confidential terms. Lewis notes that the allegations haven't been repeated since he sued. (Synagro did not respond to a request for comment on the case.)

The proposed US federal law grows out of initiatives taken by several states to deal with what is known in US libel parlance as a SLAPP (strategic lawsuit against public participation). The acronym was coined in the 1980s by Penelope Canan, a sociologist now at the University of Central Florida in Orlando, and George Pring, a law professor at the University of Denver, Colorado, to describe a meritless lawsuit brought by a corporation to intimidate people who criticize government decisions favourable to those corporations. A classic example is a suit brought by a developer against residents who oppose building plans in their towns. In response to Canan and Pring's research, many states introduced statutes that would penalize parties who brought such strategic lawsuits. A focal point for the effort has been California, where the California Anti-SLAPP Project (CASP), based in Berkeley, is now helping to craft the Citizen Partici-

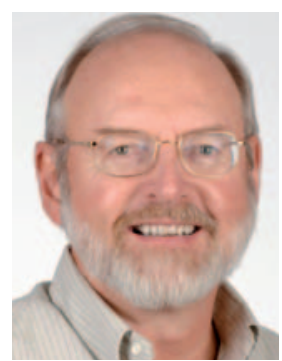

"It is the worst thing that ever happened in my life."

Daniel Klessig pation Act.

Supporters of a broad federal statute point to cases such as that of Rusi Taleyarkhan, a nuclear engineer at Purdue University in West Lafayette, Indiana, who was debarred from receiving federal funding in 2009 as a result of research-misconduct allegations brought in 2006. In 2008, Taleyarkhan sued the people who had made the allegations, including Lefteri Tsoukalas, the former head of nuclear engineering at Purdue. An Indiana court dismissed Taleyarkhan's case in December 2010, although he has since filed an appeal. Tsoukalas's defence attorney argues that the suit is a SLAPP under Indiana law, which would make Taleyarkhan responsible for both sides' legal bills, but the courts have yet to rule on this aspect of the case.

Peter Kurdock, legislative director of CASP's Public Participation Project in Washington DC, says that under the proposed federal law, whistle-blowers who could show that their comments related to a matter of public interest - such as scientific misconduct - would be able to move a case against them to a federal court where, if it lacked merit, it could

ONATURE.COM Read Nature's Editorial arguing for libel law reform at: go.nature.com/ylmatk be dismissed quickly and the responsibility for paying the legal fees could be awarded to the plaintiff.
Yet Canan, whom Kurdock credits with spearheading defamation reform in California, tells Nature that the latest legislation overreaches. "I think they're making a grave mistake," she says. Canan believes that antiSLAPP rules ought to focus on protecting comments made by citizens to the government, which come under the last clause of the US Constitution's First Amendment: the right to petition. For scientists, that would mean extra protection for comments to a government funding agency, whereas comments to the media or journal editors would be separate issues of free speech and freedom of the press. Canan's rationale is that the government has a unique need for uninhibited input to promote good governance. "I think they're watering [the issue] down by including all free speech in it," she says.

Although an earlier version of the bill was introduced in 2009, during the last Congress, by representative Steve Cohen (Democrat, Tennessee), it never made it to a vote. Kurdock says that the alliance behind the reintroduction of a revised Act is confident that this time, it will have broad-based bipartisan support. "Libel lawsuits hit every segment of society with the explosion of free speech on the Internet," he says, "and that's why we've seen a real strong interest on Capitol Hill".

The ambiguities associated with libel are most evident in instances that pit one scientist against another. In the BTI case, for example, Klessig won his lawsuit but lost a counterclaim that Chandok's suit should be designated a SLAPP under New York state statutes. This would have increased Chandok's burden of proof and required her to pay Klessig's legal fees when she lost.

\section{A NECESSARY MEASURE?}

Klessig's lawyer, Paul Battaglia of Bond, Schoeneck \& King, a law firm in Syracuse, New York, says that whistle-blowers in scientific misconduct cases urgently need anti-SLAPP legislation to be broadened. "A federal statute would be beneficial because there would be a uniform standard. It would put an added burden on the researcher who brings the lawsuit and act as a disincentive for frivolous and unmeritorious lawsuits," he says.

Kurdock says that in the United States, those who win defamation suits have little to fear from anti-SLAPP statutes, because the latest law is aimed at penalizing people who bring suits with little chance of success. But as a plaintiff who has recently lost a defamation lawsuit, Chandok feels that the ruling against her is punishment enough. She had hoped that the suit would help her to get the retractions of papers that she wrote with Klessig reversed, but that now seems unlikely. "I chose to file a lawsuit for justice for myself and postdocs everywhere. Unfortunately, I feel the court has validated everything that has been done to me," she says. 